\title{
Recent advances in MDS mutation landscape: splicing and signalling
}

Matilde Y. Follo ${ }^{1,}{ }^{*}$, Andrea Pellagatti ${ }^{2}$, Stefano Ratti ${ }^{1}$, Giulia Ramazzotti ${ }^{1}$, Irene Faenza ${ }^{1}$, Roberta Fiume ${ }^{1}$, Sara Mongiorgi ${ }^{1}$, Pann-Ghill Suh ${ }^{3,4}$, James A. McCubrey ${ }^{5}$, Lucia Manzoli ${ }^{1}$, Jacqueline Boultwood ${ }^{2}$, Lucio Cocco $^{1}$

${ }^{1}$ Cellular Signalling Laboratory, Department of Biomedical and Neuromotor Sciences, University of Bologna, Bologna, Italy; ${ }^{2}$ Bloodwise Molecular Haematology Unit, Nuffield Division of Clinical Laboratory Sciences, Radcliffe Department of Medicine, University of Oxford, and Oxford BRC Haematology Theme, Oxford, UK; ${ }^{3}$ Korea Brain Research Institute, Daegu, Republic of Korea; ${ }^{4}$ School of Life Sciences, UNIST, Ulsan, Republic of Korea; ${ }^{5}$ Department of Microbiology and Immunology, Brody School of Medicine, East Carolina University, Greenville, NC, USA.

*Corresponding author: Dr. Matilde Y. Follo, Cellular Signalling Laboratory, Department of Biomedical and Neuromotor Sciences, University of Bologna, via Irnerio 48, 40126, Bologna, Italy. Email: matilde.follo@unibo.it

Keywords: Mutations, Splicing, Signalling, Inositides, Myelodysplastic Syndromes

Running Title: Mutations in MDS: Splicing and Signalling 


\begin{abstract}
Recurrent cytogenetic aberrations, genetic mutations and variable gene expression have been consistently recognized in solid cancers and in leukaemia, including in Myelodysplastic Syndromes (MDS). Besides conventional cytogenetics, the growing accessibility of new techniques has led to a deeper analysis of the molecular significance of genetic variations. Indeed, gene mutations affecting splicing genes, as well as genes implicated in essential signalling pathways, play a pivotal role in MDS physiology and pathophysiology, representing potential new molecular targets for innovative therapeutic strategies.
\end{abstract}

\title{
Introduction
}

New techniques in molecular biology are enhancing our knowledge of the molecular landscape of cancer, as mutation analysis is able to identify specific gene alterations both at a very early stage and during disease progression, thus enabling the generation of a molecular map of cancer cells. The Myelodysplastic Syndromes (MDS) are a heterogeneous group of clonal hematological diseases that can evolve into particularly aggressive forms of Acute Myeloid Leukemia (AML). MDS patients can have a lower or higher risk of AML evolution, and the therapeutic approach is now differentially shaped around patients with lowor high-risk MDS (Platzbecker, 2019). Recurrent cytogenetic aberrations, genetic mutations and variable expression have been consistently recognized in MDS and implicated in its eventual development and are noted to be variable with regards to MDS subgroups (Shallis et al., 2018).

\section{Inositides and Cancer}

Phosphoinositides are membrane lipids that are implicated in almost all cellular physiological processes, acting as second messengers for the regulation of cell signalling, cell adhesion, motility, apoptosis, differentiation and cell cycle (Ratti et al., 2019). Some phosphoinositides can be found only in a specific organelle, such as the Golgi or the endosomes (Shewan et al., 2011; Wymann and Schneiter, 2008), but they can also be found within the nucleus, where they are regulated independently and play autonomous roles (Follo et al., 2012; Mongiorgi et al., 2012; Poli et al., 2017). In fact, these nuclear phosphoinositides perform the function of cofactors for different nuclear processes, including DNA repair and regulation of transcription (Ratti et al., 2017).

An imbalance of inositide-dependent signalling pathways, caused by a change in the composition of phosphoinositides, can lead to diseases and cancer (Blalock et al., 2011; Cocco et al., 2015a; Mongiorgi et al., 2016a). On the other hand, also a change in the inositide localization of several inositide-dependent kinases, phosphatases and phospholipases can result in an alteration of the normal cell proliferation and differentiation processes, thus leading to cancer (Follo et al., 2010; Manzoli et al., 2014; Maraldi et al., 1994; Ramazzotti et al., 2011a).

Phosphoinositide-specific phospholipase C (PI-PLC) enzymes utilize phosphoinositides as a specific substrates and their metabolism is implicated in a large series of signal transduction pathways. PI-PLC hydrolyzes phosphatidylinositol-4,5-bisphosphate (PIP2) to produce diacylglycerol (DAG) and inositol-1,4,5trisphosphate (IP3) which, in turn, activate protein kinase C (PKC) and induce the release of calcium ions from intracellular stores, respectively (Poli et al., 2014). Each PI-PLC isozyme shows a unique combination of $\mathrm{X}-\mathrm{Y}$ and regulatory domains, so that each enzyme has a proper regulation, function, and tissue 
distribution (Cocco et al., 2015b). Given their peculiar roles and their fine regulation, modifications of PIPLC isozymes have been associated with several diseases and cancerogenesis (Ramazzotti et al., 2011b). For instance, PI-PLC p plays a specific key role in cell migration and invasion, while PI-PLC $\varepsilon$ is specifically linked to tumor suppression (Martins et al., 2014), mainly in colorectal cancer, where its reduction is associated with a more aggressive disease (Wang et al., 2012)

Interestingly, PI-PLCB1 plays an essential and important role, as it behaves like a modulator in cancer. In fact, PI-PLCB1 plays an important role in brain function and myogenic differentiation (Faenza et al., 2003; Shin et al., 2016; Yang et al., 2016). But it also participates in the differentiation and activation of immune cells and is associated with hematological malignancies, such as Myelodysplastic Syndromes (MDS) (Finelli et al., 2016; Lo Vasco et al., 2004; Mongiorgi et al., 2016b; Xiao et al., 2013). Indeed, PI-PLCB1 and other inositide-specific kinases, such as PKCs or the PI3K/Akt axis, are deregulated in MDS and play essential roles in the MDS/AML progression and play a relevant role in therapy response (Poli et al., 2018) (Fili et al., 2013) (Poli A et al. FASEB J 2018; Mongiorgi et al. Exp OpinTher Targets 2016).

\section{Gene Mutations and Cancer}

Cancer cells show a great genetic instability and the presence of gene mutations can induce cell proliferation or decrease apoptosis. Recent studies showed not only that several diseases show specific gene mutations, but also that the vast majority of these disease-associated founding clones are driven by somatic mutations, with only $18 \%$ of such clones possessing a basal cytogenetic abnormality (Shallis et al., 2018).

Clonal hematopoiesis (based on the presence of somatic mutation or karyotypic aberrancy), without evidence of cytopenia or dysplasia, is more incident with increasing age and is noted in up to $10 \%$ of subjects aged 70 years or older (Genovese et al., 2014; Jaiswal et al., 2014; Xie et al., 2014). That is why in MDS the identification of recurrent somatic mutations has been important to further understand the disease pathogenesis, with the aim to determine whether they can be driver mutations.

The tumor suppressor TP53 encodes a transcription regulator involved in the regulation of the quiescence and self-renewal of hematopoietic stem cells (HSCs), through the maintenance of the balance between cell cycle, differentiation and apoptosis. TP53 gene mutations occur in approximately 8-13\% of MDS cases, and the presence of these mutations is usually linked to a worse prognosis, being associated with a shorter overall survival and an increased risk of leukemic progression (Haase et al., 2019; Shallis et al., 2018).

\section{Gene Mutations and Myelodysplastic Syndromes: Splicing Factors}

Pre-mRNA splicing plays a major role in protein regulation, as it leads to the generation of multiple protein isoforms from a single pre-mRNA transcript (Figure 1). Most of the human genes undergo splicing through the activation of the spliceosome, a complex of five small nuclear ribonucleoproteins (snRNPs), U1, U2, U4, U5 and U6, and several other associated proteins (Armstrong et al., 2018; Pellagatti and Boultwood, 2017). During the splicing process the formation of the active spliceosome occurs in a number of discrete stages involving the ordered assembly of distinct factors on the pre-mRNA substrate. Mutations in splicing factor genes or spliceosome machinery, such as those affecting SF3B1, U2AF1 and SRSF2, constitute the majority 
of abnormalities in MDS, with mutations in epigenetic regulators also being frequent, while mutation of transcription factors, kinase signalling, DNA repair, and cohesin proteins are less commonly observed.

Mutations affecting the genes encoding core spliceosome machinery do not usually result in loss-offunction phenotypes, but rather in selective splicing changes due to aberrant splice site recognition. Indeed, mutations in SF3B1, U2AF1 and SRSF2 are considered to be change of function/neomorphic or gain of function mutations, due to the presence of hotspots and the absence of nonsense or frameshift changes, but mutations in ZRSR2 are loss-of-function (Papaemmanuil et al., 2011; Yip et al., 2016; Yoshida et al., 2011). Splicing mutations have also been associated with genomic instability. This is the case for SRSF2, whose reduced levels can result in DNA damage and genomic instability through the formation of $\mathrm{R}$ loops (RNA:DNA hybrids) which, in turn, trigger activation of the DDR (Chabot and Shkreta, 2016; Pellagatti et al., 2018; Xiao et al., 2007).

RNA splicing genes (e.g. SF3B1, SRSF2, U2AF1, ZRSR2) are mutated in several hematological malignancies, including AML, but are strongly associated with the MDS phenotype, where they can be founder mutations (Shallis et al., 2018). Indeed, the molecular landscape of MDS has been illuminated by the identification of specific splicing factor gene mutations, which are typically heterozygous and occur in over half of all de novo MDS patients, thus being the most common molecular abnormality of this disorder (Mian et al., 2015; Mian et al., 2013; Papaemmanuil et al., 2011; Pellagatti and Boultwood, 2017; Yoshida et al., 2011). While splicing factor mutations can be found in isolation (Mian et al., 2013), several studies have shown that these mutations also show specific associations with other recurrently mutated genes, such as epigenetic regulators or other oncogenes (Haferlach et al., 2014; Papaemmanuil et al., 2013).

Mutations in the SF3B1 gene, which encodes a key subunit of the spliceosome, were among the first spliceosomal mutations discovered in MDS and are now recognized as the most common splicing factor mutation in these patients, occurring in $20 \%-28 \%$ of cases (Malcovati et al., 2011; Papaemmanuil et al., 2011; Yoshida et al., 2011). SF3B1 mutations are strongly associated with the presence of ring sideroblasts in the bone marrow (Malcovati et al., 2011) and are predictive of a favorable prognosis in MDS (Malcovati et al., 2011; Papaemmanuil et al., 2011), while SRSF2 and U2AF1 mutations have been associated with a higher risk of transformation to AML (Pellagatti and Boultwood, 2017).

Splicing factor mutations have been shown to lead to aberrant $3^{\prime}$ splice site recognition, resulting in aberrant splicing of many target genes in MDS (Pellagatti et al., 2018; Shiozawa et al., 2018). Recent functional studies have investigated the impact on hematopoiesis of some of the aberrantly spliced target genes associated with splicing factor gene mutations. For example splicing aberrations of $A B C B 7$ (associated with SF3B1 mutations), EZH2 (associated with SRSF2 mutations), and STRAP and H2AFY (associated with U2AF1 mutations), have been linked to some of the hematological abnormalities that are observed in MDS (Dolatshad et al., 2016; Joshi et al., 2017; Lee et al., 2018; Saez et al., 2017; Yip et al., 2017). In a recent study, missplicing of BRD9 (a core component of the non-canonical BAF complex) has been shown to occur in SF3B1 mutant cancers, including MDS (Inoue et al., 2019). In AML, U2AF1 mutations have been associated with abnormal splicing of several genes known to be mutated in cancer and in many genes involved in specific cellular pathways, including RNA processing, cell cycle and the DNA damage response (Przychodzen et al., 2013). Aberrant splicing of IRAK4 in MDS and AML is an example in which mutant U2AF1 generates an isoform with oncogenic activity (Smith et al., 2019). 
Cellular pathways, including those involved in DNA transcription, signal transduction, and epigenetic regulation, are strongly controlled by genetic factors (Figure 1). Somatic mutations in many of the genes vital to these processes have been identified in cancer, includingin MDS, where up to $78 \%-89 \%$ of patients across various subtypes of MDS show a median of three somatic mutations per patient and are associated with MDS pathogenesis. These mutations are frequently observed at diagnosis, but they can also be acquired during disease progression or relapse following therapy (Pellagatti et al., 2018).

Mutations in epigenetic regulators have been identified in cases of MDS with no apparent spliceosome mutation, implying that this latter is frequent but not mandatory for the development of the phenotype (Shallis et al., 2018). ASXL1, encoding an epigenetic regulator, was the top ranking mutated gene in a study of MDS patients that progressed to advanced disease or to AML, with a frequency of $44 \%$ in preprogression samples and $46 \%$ in post-progression samples (Pellagatti et al., 2016). Moreover, cooccurrence of RUNX1 and ASXL1 mutations was also associated with poor response to hypomethylating agents and inferior survival (Wu et al., 2019).

Not only ASXL1 mutations were associated with impaired hematopoiesis and can be predictive of a poor outcome (Mangaonkar et al., 2018; Uni et al., 2019), but also TP53 and EZH2 mutations have been recognized as being unfavorable for survival in MDS (Arbab Jafari et al., 2018; Gangat et al., 2018; Smeets et al., 2018). EZH2 gene is involved in chromatin remodelling and is mutated in approximately $15-25 \%$ MDS, along with mutations in DNA methylation genes (i.e. DNMT3A, TET2, IDH1, IDH2; approximately 30$40 \%$ ). No prognostic significance has been ascribed to the TET2 mutations in MDS, but the presence of a TET2 mutation (specifically in the absence of an ASXL1 mutation) was associated with a better response to the irreversible DNA methyltransferase inhibitors azacitidine and decitabine (Shallis et al., 2018; Unnikrishnan et al., 2017), while the acquisition of TP53 or NRAS mutations has recently been related to lenalidomide resistance (da Silva-Coelho et al., 2017; Jadersten et al., 2011). Indeed, several permutations of RAS (NRAS, KRAS and HRAS) exist and may uncommonly be mutated in MDS.

Splicing factor gene mutations in MDS can also result in activation of NF-KB signaling (Lee et al., 2018; Smith et al., 2019), which is associated with innate immunity and inflammation, as well as in the dysregulation of Sirtuin signalling (Pellagatti et al., 2018). Sirtuins are histone deacetylases, some of which reside in the mitochondria (Carrico et al., 2018), with diverse roles in regulating metabolism, inflammation, genome stability, and cell proliferation, and have been implicated in aging, cancer and survival (Roth and Chen, 2014; Roth et al., 2013).

Dysregulation of cell growth is a feature of MDS (Heaney and Golde, 1999). Genes regulated by the transcriptional regulators HNF4A, RICTOR, E2F1, MYC, MYCN, and RB1, all major controllers of cell growth/cell cycle (Hallstrom et al., 2008; Huang et al., 2011; Jebali and Dumaz, 2018), showed significant enrichment for aberrantly spliced genes associated with splicing factor gene mutations in MDS (Pellagatti et al., 2018). Interestingly HNF4A inhibition promotes tumorigenesis in solid cancers (Nakajima et al., 2018).

Normal cellular growth and differentiation are regulated by other important signalling pathways, that can be mutated in MDS. For instance, mutations leading to abnormal and overactive tyrosine kinase JAK (Janus kinase)/STAT (signal transducer and activator of transcription proteins) signalling and ensuing myelopoiesis have been implicated in a small subset of MDS (Shallis et al., 2018), like the mitogen-activated protein (MAP) and phosphatidylinositol-3 kinase (PI3K)/AKT/mTOR pathways.

As for this latter, isoform-specific Akt deregulation is frequently observed in different types of cancer, especially in hematological malignancies. For instance, AKT3 impairment has been associated with multiple 
myeloma (Li and Ma, 2018; Li et al., 2018), and de novo Philadelphia chromosome-positive AML frequently show mutations of AKT3 and PI3KCD genes (Konoplev et al., 2013). Indeed, the immune and leukocyte-

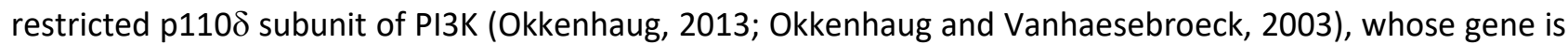
PI3KCD, plays an important role in cell proliferation and has been proposed as a potential target in the treatment of AML (Billottet et al., 2006; Sujobert et al., 2005; Xie et al., 2017). Moreover, recent studies showed that PIK3CD germline mutations in B-cells can lead to either gain or loss of function of PI3K $\delta$, resulting in immune dysregulation (Avery et al., 2018; Compagno et al., 2017).

Recently, the presence of specific three point mutations affecting three important inositide genes (PI3KCD, AKT3 and PLCG2) was correlated to a negative response to azacitidine and lenalidomide therapy, resulting in a worse clinical outcome (Follo et al., 2019). In that study, all MDS patients early losing response, as well as cases never responding, acquired the same 3 point mutations during therapy, affecting respectively PIK3CD (D133E), AKT3 (D280G) and PLCG2 (Q548R) genes. Interestingly, PI3KCD and AKT3 genes are actively involved in cell proliferation. That is why the acquisition of these specific point mutations in MDS not responding to therapy could give a proliferative advantage to mutated cells. On the other hand, as PLCG2 has been associated with myeloid differentiation, it is also likely that the acquisition of this specific point mutation in non responder MDS patients could result in an impaired hematopoietic differentiation and a subsequent stable disease or AML progression. Although this was a preliminary analysis, performed on a relatively small number of cases, the statistically significant association between this cluster and a shorter duration of response could pave the way to larger studies.

\section{Conclusions}

In MDS, the identification of new molecular markers can be very useful, not only to make a better diagnosis and patient's risk stratification, but also to predict the effect of the therapy or develop innovative targeted therapeutic strategies. Moreover, as one of the main concerns in MDS is the progression to AML, some of these molecular markers could also predict the clinical outcome of MDS patients, and indeed this has been shown for some mutated genes (Haase et al., 2019).

Up to $90 \%$ of MDS patients harbour one or more gene mutations. That is why molecular data are now increasingly important to characterize MDS patients, and multiple molecular markers that were identified in the last few years are now becoming more and more important in MDS.

Given the prevalence of RNA splicing gene mutations in MDS and in hematologic malignancies, effective strategies to therapeutically target spliceosome mutant cells, such as small molecule modulators of the spliceosome that interfere with the splicing machinery and alter 3' splice site recognition, are needed. Moreover, new prognostic panels of specific mutations associated with MDS disease progression, epigenetic therapy response/resistance or disease predisposition could also be important, as a targeted approach, based on few mutations, would be not only cost-effective but also rapidly clinically applicable.

Finally, as not only somatic, but also germline mutations play important roles in both cancer pathogenesis and development, a deeper analysis on germline mutations could be relevant for MDS pathogenesis. 


\section{Acknowledgments}

This work was supported by Italian MIUR-PRIN and Intesa San Paolo Foundation. AP and JB are supported by Bloodwise grants.

\section{References}

Arbab Jafari, P., Ayatollahi, H., Sadeghi, R., Sheikhi, M., Asghari, A., 2018. Prognostic significance of SRSF2 mutations in myelodysplastic syndromes and chronic myelomonocytic leukemia: a meta-analysis. Hematology, 1-7.

Armstrong, R.N., Steeples, V., Singh, S., Sanchi, A., Boultwood, J., Pellagatti, A., 2018. Splicing factor mutations in the myelodysplastic syndromes: target genes and therapeutic approaches. Adv Biol Regul 67, 13-29.

Avery, D.T., Kane, A., Nguyen, T., Lau, A., Nguyen, A., Lenthall, H., Payne, K., Shi, W., Brigden, H., French, E., Bier, J., Hermes, J.R., Zahra, D., Sewell, W.A., Butt, D., Elliott, M., Boztug, K., Meyts, I., Choo, S., Hsu, P., Wong, M., Berglund, L.J., Gray, P., O'Sullivan, M., Cole, T., Holland, S.M., Ma, C.S., Burkhart, C., Corcoran, L.M., Phan, T.G., Brink, R., Uzel, G., Deenick, E.K., Tangye, S.G., 2018. Germline-activating mutations in PIK3CD compromise B cell development and function. J Exp Med 215(8), 2073-2095.

Billottet, C., Grandage, V.L., Gale, R.E., Quattropani, A., Rommel, C., Vanhaesebroeck, B., Khwaja, A., 2006. A selective inhibitor of the p110delta isoform of PI 3-kinase inhibits AML cell proliferation and survival and increases the cytotoxic effects of VP16. Oncogene 25(50), 6648-6659.

Blalock, W.L., Bavelloni, A., Piazzi, M., Tagliavini, F., Faenza, I., Martelli, A.M., Follo, M.Y., Cocco, L., 2011. Multiple forms of PKR present in the nuclei of acute leukemia cells represent an active kinase that is responsive to stress. Leukemia 25(2), 236-245.

Carrico, C., Meyer, J.G., He, W., Gibson, B.W., Verdin, E., 2018. The Mitochondrial Acylome Emerges: Proteomics, Regulation by Sirtuins, and Metabolic and Disease Implications. Cell Metab 27(3), 497-512.

Chabot, B., Shkreta, L., 2016. Defective control of pre-messenger RNA splicing in human disease. J Cell Biol 212(1), 13-27.

Cocco, L., Finelli, C., Mongiorgi, S., Clissa, C., Russo, D., Bosi, C., Quaranta, M., Malagola, M., Parisi, S., Stanzani, M., Ramazzotti, G., Mariani, G.A., Billi, A.M., Manzoli, L., Follo, M.Y., 2015a. An increased expression of PI-PLCbeta1 is associated with myeloid differentiation and a longer response to azacitidine in myelodysplastic syndromes. J Leukoc Biol 98(5), 769-780.

Cocco, L., Follo, M.Y., Manzoli, L., Suh, P.G., 2015b. Phosphoinositide-specific phospholipase C in health and disease. J Lipid Res 56(10), 1853-1860.

Compagno, M., Wang, Q., Pighi, C., Cheong, T.C., Meng, F.L., Poggio, T., Yeap, L.S., Karaca, E., Blasco, R.B., Langellotto, F., Ambrogio, C., Voena, C., Wiestner, A., Kasar, S.N., Brown, J.R., Sun, J., Wu, C.J., Gostissa, M., Alt, F.W., Chiarle, R., 2017. Phosphatidylinositol 3-kinase delta blockade increases genomic instability in B cells. Nature 542(7642), 489-493.

da Silva-Coelho, P., Kroeze, L.I., Yoshida, K., Koorenhof-Scheele, T.N., Knops, R., van de Locht, L.T., de Graaf, A.O., Massop, M., Sandmann, S., Dugas, M., Stevens-Kroef, M.J., Cermak, J., Shiraishi, Y., Chiba, K., Tanaka, H., Miyano, S., de Witte, T., Blijlevens, N.M.A., Muus, P., Huls, G., van der Reijden, B.A., Ogawa, S., Jansen, J.H., 2017. Clonal evolution in myelodysplastic syndromes. Nat Commun 8(15099), 1-11.

Dolatshad, H., Pellagatti, A., Liberante, F.G., Llorian, M., Repapi, E., Steeples, V., Roy, S., Scifo, L., Armstrong, R.N., Shaw, J., Yip, B.H., Killick, S., Kusec, R., Taylor, S., Mills, K.I., Savage, K.I., Smith, C.W., Boultwood, J., 2016. Cryptic splicing events in the iron transporter ABCB7 and other key target genes in SF3B1-mutant myelodysplastic syndromes. Leukemia 30(12), 2322-2331.

Faenza, I., Bavelloni, A., Fiume, R., Lattanzi, G., Maraldi, N.M., Gilmour, R.S., Martelli, A.M., Suh, P.G., Billi, A.M., Cocco, L., 2003. Up-regulation of nuclear PLCbeta1 in myogenic differentiation. J Cell Physiol 195(3), 446-452.

Fili, C., Malagola, M., Follo, M.Y., Finelli, C., lacobucci, I., Martinelli, G., Cattina, F., Clissa, C., Candoni, A., Fanin, R., Gobbi, M., Bocchia, M., Defina, M., Spedini, P., Skert, C., Manzoli, L., Cocco, L., Russo, D., 2013. 
Prospective phase II Study on 5-days azacitidine for treatment of symptomatic and/or erythropoietin unresponsive patients with low/INT-1-risk myelodysplastic syndromes. Clin Cancer Res 19(12), 3297-3308.

Finelli, C., Follo, M.Y., Stanzani, M., Parisi, S., Clissa, C., Mongiorgi, S., Barraco, M., Cocco, L., 2016. Clinical Impact of Hypomethylating Agents in the Treatment of Myelodysplastic Syndromes. Curr Pharm Des 22(16), 2349-2357.

Follo, M.Y., Mongiorgi, S., Finelli, C., Clissa, C., Ramazzotti, G., Fiume, R., Faenza, I., Manzoli, L., Martelli, A.M., Cocco, L., 2010. Nuclear inositide signaling in myelodysplastic syndromes. J Cell Biochem 109(6), 1065-1071.

Follo, M.Y., Mongiorgi, S., Finelli, C., Piazzi, M., Faenza, I., Ramazzotti, G., Santi, P., McCubrey, J.A., Martelli, A.M., Cocco, L., 2012. Nuclear PI-PLCbeta1 and myelodysplastic syndromes: genetics and epigenetics. Curr Pharm Des 18(13), 1751-1754.

Follo, M.Y., Pellagatti, A., Armstrong, R.N., Ratti, S., Mongiorgi, S., De Fanti, S., Bochicchio, M.T., Russo, D., Gobbi, M., Miglino, M., Parisi, S., Martinelli, G., Cavo, M., Luiselli, D., McCubrey, J.A., Suh, P.G., Manzoli, L., Boultwood, J., Finelli, C., Cocco, L., 2019. Response of high-risk MDS to azacitidine and lenalidomide is impacted by baseline and acquired mutations in a cluster of three inositide-specific genes. Leukemia 33(9), 2276-2290.

Gangat, N., Mudireddy, M., Lasho, T.L., Finke, C.M., Nicolosi, M., Szuber, N., Patnaik, M.M., Pardanani, A., Hanson, C.A., Ketterling, R.P., Tefferi, A., 2018. Mutations and prognosis in myelodysplastic syndromes: karyotype-adjusted analysis of targeted sequencing in 300 consecutive cases and development of a genetic risk model. Am J Hematol 93(5), 691-697.

Genovese, G., Kahler, A.K., Handsaker, R.E., Lindberg, J., Rose, S.A., Bakhoum, S.F., Chambert, K., Mick, E., Neale, B.M., Fromer, M., Purcell, S.M., Svantesson, O., Landen, M., Hoglund, M., Lehmann, S., Gabriel, S.B., Moran, J.L., Lander, E.S., Sullivan, P.F., Sklar, P., Gronberg, H., Hultman, C.M., McCarroll, S.A., 2014. Clonal hematopoiesis and blood-cancer risk inferred from blood DNA sequence. N Engl J Med 371(26), 2477-2487.

Haase, D., Stevenson, K.E., Neuberg, D., Maciejewski, J.P., Nazha, A., Sekeres, M.A., Ebert, B.L., GarciaManero, G., Haferlach, C., Haferlach, T., Kern, W., Ogawa, S., Nagata, Y., Yoshida, K., Graubert, T.A., Walter, M.J., List, A.F., Komrokji, R.S., Padron, E., Sallman, D., Papaemmanuil, E., Campbell, P.J., Savona, M.R., Seegmiller, A., Ades, L., Fenaux, P., Shih, L.Y., Bowen, D., Groves, M.J., Tauro, S., Fontenay, M., Kosmider, O., Bar-Natan, M., Steensma, D., Stone, R., Heuser, M., Thol, F., Cazzola, M., Malcovati, L., Karsan, A., Ganster, C., Hellstrom-Lindberg, E., Boultwood, J., Pellagatti, A., Santini, V., Quek, L., Vyas, P., Tuchler, H., Greenberg, P.L., Bejar, R., 2019. TP53 mutation status divides myelodysplastic syndromes with complex karyotypes into distinct prognostic subgroups. Leukemia 33(7), 1747-1758.

Haferlach, T., Nagata, Y., Grossmann, V., Okuno, Y., Bacher, U., Nagae, G., Schnittger, S., Sanada, M., Kon, A., Alpermann, T., Yoshida, K., Roller, A., Nadarajah, N., Shiraishi, Y., Shiozawa, Y., Chiba, K., Tanaka, H., Koeffler, H.P., Klein, H.U., Dugas, M., Aburatani, H., Kohlmann, A., Miyano, S., Haferlach, C., Kern, W., Ogawa, S., 2014. Landscape of genetic lesions in 944 patients with myelodysplastic syndromes. Leukemia 28(2), 241-247.

Hallstrom, T.C., Mori, S., Nevins, J.R., 2008. An E2F1-dependent gene expression program that determines the balance between proliferation and cell death. Cancer Cell 13(1), 11-22.

Heaney, M.L., Golde, D.W., 1999. Myelodysplasia. N Engl J Med 340(21), 1649-1660.

Huang, R., Cheung, N.K., Vider, J., Cheung, I.Y., Gerald, W.L., Tickoo, S.K., Holland, E.C., Blasberg, R.G., 2011. MYCN and MYC regulate tumor proliferation and tumorigenesis directly through BMI1 in human neuroblastomas. FASEB J 25(12), 4138-4149.

Inoue, D., Chew, G.L., Liu, B., Michel, B.C., Pangallo, J., D'Avino, A.R., Hitchman, T., North, K., Lee, S.C., Bitner, L., Block, A., Moore, A.R., Yoshimi, A., Escobar-Hoyos, L., Cho, H., Penson, A., Lu, S.X., Taylor, J., Chen, Y., Kadoch, C., Abdel-Wahab, O., Bradley, R.K., 2019. Spliceosomal disruption of the non-canonical BAF complex in cancer. Nature.

Jadersten, M., Saft, L., Smith, A., Kulasekararaj, A., Pomplun, S., Gohring, G., Hedlund, A., Hast, R., Schlegelberger, B., Porwit, A., Hellstrom-Lindberg, E., Mufti, G.J., 2011. TP53 mutations in low-risk myelodysplastic syndromes with del(5q) predict disease progression. J Clin Oncol 29(15), 1971-1979.

Jaiswal, S., Fontanillas, P., Flannick, J., Manning, A., Grauman, P.V., Mar, B.G., Lindsley, R.C., Mermel, C.H., Burtt, N., Chavez, A., Higgins, J.M., Moltchanov, V., Kuo, F.C., Kluk, M.J., Henderson, B., Kinnunen, L., Koistinen, H.A., Ladenvall, C., Getz, G., Correa, A., Banahan, B.F., Gabriel, S., Kathiresan, S., Stringham, H.M., 
McCarthy, M.I., Boehnke, M., Tuomilehto, J., Haiman, C., Groop, L., Atzmon, G., Wilson, J.G., Neuberg, D., Altshuler, D., Ebert, B.L., 2014. Age-related clonal hematopoiesis associated with adverse outcomes. N Engl J Med 371(26), 2488-2498.

Jebali, A., Dumaz, N., 2018. The role of RICTOR downstream of receptor tyrosine kinase in cancers. Mol Cancer 17(1), 1-10.

Joshi, P., Halene, S., Abdel-Wahab, O., 2017. How do messenger RNA splicing alterations drive myelodysplasia? Blood 129(18), 2465-2470.

Konoplev, S., Yin, C.C., Kornblau, S.M., Kantarjian, H.M., Konopleva, M., Andreeff, M., Lu, G., Zuo, Z., Luthra, R., Medeiros, L.J., Bueso-Ramos, C.E., 2013. Molecular characterization of de novo Philadelphia chromosome-positive acute myeloid leukemia. Leuk Lymphoma 54(1), 138-144.

Lee, S.C., North, K., Kim, E., Jang, E., Obeng, E., Lu, S.X., Liu, B., Inoue, D., Yoshimi, A., Ki, M., Yeo, M., Zhang, X.J., Kim, M.K., Cho, H., Chung, Y.R., Taylor, J., Durham, B.H., Kim, Y.J., Pastore, A., Monette, S., Palacino, J., Seiler, M., Buonamici, S., Smith, P.G., Ebert, B.L., Bradley, R.K., Abdel-Wahab, O., 2018. Synthetic Lethal and Convergent Biological Effects of Cancer-Associated Spliceosomal Gene Mutations. Cancer Cell 34(2), 225241 e228.

Li, L., Ma, L., 2018. Upregulation of miR-582-5p regulates cell proliferation and apoptosis by targeting AKT3 in human endometrial carcinoma. Saudi J Biol Sci 25(5), 965-970.

Li, Q.Y., Chen, L., Hu, N., Zhao, H., 2018. Long non-coding RNA FEZF1-AS1 promotes cell growth in multiple myeloma via miR-610/Akt3 axis. Biomed Pharmacother 103, 1727-1732.

Lo Vasco, V.R., Calabrese, G., Manzoli, L., Palka, G., Spadano, A., Morizio, E., Guanciali-Franchi, P., Fantasia, D., Cocco, L., 2004. Inositide-specific phospholipase c beta1 gene deletion in the progression of myelodysplastic syndrome to acute myeloid leukemia. Leukemia 18(6), 1122-1126.

Malcovati, L., Papaemmanuil, E., Bowen, D.T., Boultwood, J., Della Porta, M.G., Pascutto, C., Travaglino, E., Groves, M.J., Godfrey, A.L., Ambaglio, I., Galli, A., Da Via, M.C., Conte, S., Tauro, S., Keenan, N., Hyslop, A., Hinton, J., Mudie, L.J., Wainscoat, J.S., Futreal, P.A., Stratton, M.R., Campbell, P.J., Hellstrom-Lindberg, E., Cazzola, M., 2011. Clinical significance of SF3B1 mutations in myelodysplastic syndromes and myelodysplastic/myeloproliferative neoplasms. Blood 118(24), 6239-6246.

Mangaonkar, A.A., Gangat, N., Al-Kali, A., Elliott, M.A., Begna, K.H., Hanson, C.A., Ketterling, R.P., Wolanskyj-Spinner, A.P., Hogan, W.J., Litzow, M.R., Patnaik, M.M., 2018. Prognostic impact of ASXL1 mutations in patients with myelodysplastic syndromes and multilineage dysplasia with or without ring sideroblasts. Leuk Res 71, 60-62.

Manzoli, L., Mongiorgi, S., Clissa, C., Finelli, C., Billi, A.M., Poli, A., Quaranta, M., Cocco, L., Follo, M.Y., 2014. Strategic Role of Nuclear Inositide Signalling in Myelodysplastic Syndromes Therapy. Mini Rev Med Chem 14(11), 873-883.

Maraldi, N.M., Cocco, L., Capitani, S., Mazzotti, G., Barnabei, O., Manzoli, F.A., 1994. Lipid-dependent nuclear signalling: morphological and functional features. Adv Enzyme Regul 34, 129-143.

Martins, M., McCarthy, A., Baxendale, R., Guichard, S., Magno, L., Kessaris, N., El-Bahrawy, M., Yu, P., Katan, M., 2014. Tumor suppressor role of phospholipase C epsilon in Ras-triggered cancers. Proc Natl Acad Sci U S A 111(11), 4239-4244.

Mian, S.A., Rouault-Pierre, K., Smith, A.E., Seidl, T., Pizzitola, I., Kizilors, A., Kulasekararaj, A.G., Bonnet, D., Mufti, G.J., 2015. SF3B1 mutant MDS-initiating cells may arise from the haematopoietic stem cell compartment. Nat Commun 6(10004), 1-14.

Mian, S.A., Smith, A.E., Kulasekararaj, A.G., Kizilors, A., Mohamedali, A.M., Lea, N.C., Mitsopoulos, K., Ford, K., Nasser, E., Seidl, T., Mufti, G.J., 2013. Spliceosome mutations exhibit specific associations with epigenetic modifiers and proto-oncogenes mutated in myelodysplastic syndrome. Haematologica 98(7), 1058-1066.

Mongiorgi, S., Finelli, C., Yang, Y.R., Clissa, C., McCubrey, J.A., Billi, A.M., Manzoli, L., Suh, P.G., Cocco, L., Follo, M.Y., 2016a. Inositide-dependent signaling pathways as new therapeutic targets in myelodysplastic syndromes. Expert Opin Ther Targets 20(6), 677-687.

Mongiorgi, S., Follo, M.Y., Clissa, C., Giardino, R., Fini, M., Manzoli, L., Ramazzotti, G., Fiume, R., Finelli, C., Cocco, L., 2012. Nuclear PI-PLC beta1 and Myelodysplastic syndromes: from bench to clinics. Curr Top Microbiol Immunol 362, 235-245. 
Mongiorgi, S., Follo, M.Y., Yang, Y.R., Ratti, S., Manzoli, L., McCubrey, J.A., Billi, A.M., Suh, P.G., Cocco, L., 2016b. Selective Activation of Nuclear PI-PLCbeta1 During Normal and Therapy-Related Differentiation. Curr Pharm Des 22(16), 2345-2348.

Nakajima, N., Yoshizawa, A., Nakajima, T., Hirata, M., Furuhata, A., Sumiyoshi, S., Rokutan-Kurata, M., Sonobe, M., Menju, T., Miyamoto, E., Chen-Yoshikawa, T.F., Date, H., Haga, H., 2018. GATA6-positive lung adenocarcinomas are associated with invasive mucinous adenocarcinoma morphology, hepatocyte nuclear factor 4alpha expression, and KRAS mutations. Histopathology 73(1), 38-48.

Okkenhaug, K., 2013. Signaling by the phosphoinositide 3-kinase family in immune cells. Annu Rev Immunol 31, 675-704.

Okkenhaug, K., Vanhaesebroeck, B., 2003. PI3K in lymphocyte development, differentiation and activation. Nat Rev Immunol 3(4), 317-330.

Papaemmanuil, E., Cazzola, M., Boultwood, J., Malcovati, L., Vyas, P., Bowen, D., Pellagatti, A., Wainscoat, J.S., Hellstrom-Lindberg, E., Gambacorti-Passerini, C., Godfrey, A.L., Rapado, I., Cvejic, A., Rance, R., McGee, C., Ellis, P., Mudie, L.J., Stephens, P.J., McLaren, S., Massie, C.E., Tarpey, P.S., Varela, I., Nik-Zainal, S., Davies, H.R., Shlien, A., Jones, D., Raine, K., Hinton, J., Butler, A.P., Teague, J.W., Baxter, E.J., Score, J., Galli, A., Della Porta, M.G., Travaglino, E., Groves, M., Tauro, S., Munshi, N.C., Anderson, K.C., El-Naggar, A., Fischer, A., Mustonen, V., Warren, A.J., Cross, N.C., Green, A.R., Futreal, P.A., Stratton, M.R., Campbell, P.J., 2011. Somatic SF3B1 mutation in myelodysplasia with ring sideroblasts. N Engl J Med 365(15), 1384-1395.

Papaemmanuil, E., Gerstung, M., Malcovati, L., Tauro, S., Gundem, G., Van Loo, P., Yoon, C.J., Ellis, P., Wedge, D.C., Pellagatti, A., Shlien, A., Groves, M.J., Forbes, S.A., Raine, K., Hinton, J., Mudie, L.J., McLaren, S., Hardy, C., Latimer, C., Della Porta, M.G., O'Meara, S., Ambaglio, I., Galli, A., Butler, A.P., Walldin, G., Teague, J.W., Quek, L., Sternberg, A., Gambacorti-Passerini, C., Cross, N.C., Green, A.R., Boultwood, J., Vyas, P., Hellstrom-Lindberg, E., Bowen, D., Cazzola, M., Stratton, M.R., Campbell, P.J., 2013. Clinical and biological implications of driver mutations in myelodysplastic syndromes. Blood 122(22), 3616-3627; quiz 3699.

Pellagatti, A., Armstrong, R.N., Steeples, V., Sharma, E., Repapi, E., Singh, S., Sanchi, A., Radujkovic, A., Horn, P., Dolatshad, H., Roy, S., Broxholme, J., Lockstone, H., Taylor, S., Giagounidis, A., Vyas, P., Schuh, A., Hamblin, A., Papaemmanuil, E., Killick, S., Malcovati, L., Hennrich, M.L., Gavin, A.C., Ho, A.D., Luft, T., Hellstrom-Lindberg, E., Cazzola, M., Smith, C.W.J., Smith, S., Boultwood, J., 2018. Impact of spliceosome mutations on RNA splicing in myelodysplasia: dysregulated genes/pathways and clinical associations. Blood 132(12), 1225-1240.

Pellagatti, A., Boultwood, J., 2017. Splicing factor gene mutations in the myelodysplastic syndromes: impact on disease phenotype and therapeutic applications. Adv Biol Regul 63, 59-70.

Pellagatti, A., Roy, S., Di Genua, C., Burns, A., McGraw, K., Valletta, S., Larrayoz, M.J., Fernandez-Mercado, M., Mason, J., Killick, S., Mecucci, C., Calasanz, M.J., List, A., Schuh, A., Boultwood, J., 2016. Targeted resequencing analysis of 31 genes commonly mutated in myeloid disorders in serial samples from myelodysplastic syndrome patients showing disease progression. Leukemia 30(1), 247-250.

Platzbecker, U., 2019. Treatment of MDS. Blood 133(10), 1096-1107.

Poli, A., Fiume, R., Baldanzi, G., Capello, D., Ratti, S., Gesi, M., Manzoli, L., Graziani, A., Suh, P.G., Cocco, L., Follo, M.Y., 2017. Nuclear Localization of Diacylglycerol Kinase Alpha in K562 Cells Is Involved in Cell Cycle Progression. J Cell Physiol 232(9), 2550-2557.

Poli, A., Mongiorgi, S., Cocco, L., Follo, M.Y., 2014. Protein kinase C involvement in cell cycle modulation. Biochem Soc Trans 42(5), 1471-1476.

Poli, A., Ratti, S., Finelli, C., Mongiorgi, S., Clissa, C., Lonetti, A., Cappellini, A., Catozzi, A., Barraco, M., Suh, P.G., Manzoli, L., McCubrey, J.A., Cocco, L., Follo, M.Y., 2018. Nuclear translocation of PKC-alpha is associated with cell cycle arrest and erythroid differentiation in myelodysplastic syndromes (MDSs). FASEB J 32(2), 681-692.

Przychodzen, B., Jerez, A., Guinta, K., Sekeres, M.A., Padgett, R., Maciejewski, J.P., Makishima, H., 2013. Patterns of missplicing due to somatic U2AF1 mutations in myeloid neoplasms. Blood 122(6), 999-1006.

Ramazzotti, G., Faenza, I., Fiume, R., Matteucci, A., Piazzi, M., Follo, M.Y., Cocco, L., 2011a. The physiology and pathology of inositide signaling in the nucleus. J Cell Physiol 226(1), 14-20.

Ramazzotti, G., Faenza, I., Follo, M.Y., Fiume, R., Piazzi, M., Giardino, R., Fini, M., Cocco, L., 2011b. Nuclear phospholipase $C$ in biological control and cancer. Crit Rev Eukaryot Gene Expr 21(3), 291-301. 
Ratti, S., Follo, M.Y., Ramazzotti, G., Faenza, I., Fiume, R., Suh, P.G., McCubrey, J.A., Manzoli, L., Cocco, L., 2019. Nuclear phospholipase $C$ isoenzyme imbalance leads to pathologies in brain, hematologic, neuromuscular, and fertility disorders. J Lipid Res 60(2), 312-317.

Ratti, S., Mongiorgi, S., Ramazzotti, G., Follo, M.Y., Mariani, G.A., Suh, P.G., McCubrey, J.A., Cocco, L., Manzoli, L., 2017. Nuclear Inositide Signaling Via Phospholipase C. J Cell Biochem 118(8), 1969-1978.

Roth, M., Chen, W.Y., 2014. Sorting out functions of sirtuins in cancer. Oncogene 33(13), 1609-1620.

Roth, M., Wang, Z., Chen, W.Y., 2013. Sirtuins in hematological aging and malignancy. Crit Rev Oncog 18(6), 531-547.

Saez, B., Walter, M.J., Graubert, T.A., 2017. Splicing factor gene mutations in hematologic malignancies. Blood 129(10), 1260-1269.

Shallis, R.M., Ahmad, R., Zeidan, A.M., 2018. The genetic and molecular pathogenesis of myelodysplastic syndromes. Eur J Haematol 101(3), 260-271.

Shewan, A., Eastburn, D.J., Mostov, K., 2011. Phosphoinositides in cell architecture. Cold Spring Harb Perspect Biol 3(a004796), 1-18.

Shin, K.J., Lee, Y.J., Yang, Y.R., Park, S., Suh, P.G., Follo, M.Y., Cocco, L., Ryu, S.H., 2016. Molecular Mechanisms Underlying Psychological Stress and Cancer. Curr Pharm Des 22(16), 2389-2402.

Shiozawa, Y., Malcovati, L., Galli, A., Sato-Otsubo, A., Kataoka, K., Sato, Y., Watatani, Y., Suzuki, H., Yoshizato, T., Yoshida, K., Sanada, M., Makishima, H., Shiraishi, Y., Chiba, K., Hellstrom-Lindberg, E., Miyano, S., Ogawa, S., Cazzola, M., 2018. Aberrant splicing and defective mRNA production induced by somatic spliceosome mutations in myelodysplasia. Nat Commun 9(1), 3649.

Smeets, M.F., Tan, S.Y., Xu, J.J., Anande, G., Unnikrishnan, A., Chalk, A.M., Taylor, S.R., Pimanda, J.E., Wall, M., Purton, L.E., Walkley, C.R., 2018. Srsf2(P95H) initiates myeloid bias and myelodysplastic/myeloproliferative syndrome from hemopoietic stem cells. Blood 132(6), 608-621.

Smith, M.A., Choudhary, G.S., Pellagatti, A., Choi, K., Bolanos, L.C., Bhagat, T.D., Gordon-Mitchell, S., Von Ahrens, D., Pradhan, K., Steeples, V., Kim, S., Steidl, U., Walter, M., Fraser, I.D.C., Kulkarni, A., Salomonis, N., Komurov, K., Boultwood, J., Verma, A., Starczynowski, D.T., 2019. U2AF1 mutations induce oncogenic IRAK4 isoforms and activate innate immune pathways in myeloid malignancies. Nat Cell Biol 21(5), 640-650.

Sujobert, P., Bardet, V., Cornillet-Lefebvre, P., Hayflick, J.S., Prie, N., Verdier, F., Vanhaesebroeck, B., Muller, O., Pesce, F., Ifrah, N., Hunault-Berger, M., Berthou, C., Villemagne, B., Jourdan, E., Audhuy, B., Solary, E., Witz, B., Harousseau, J.L., Himberlin, C., Lamy, T., Lioure, B., Cahn, J.Y., Dreyfus, F., Mayeux, P., Lacombe, C., Bouscary, D., 2005. Essential role for the p110delta isoform in phosphoinositide 3-kinase activation and cell proliferation in acute myeloid leukemia. Blood 106(3), 1063-1066.

Uni, M., Masamoto, Y., Sato, T., Kamikubo, Y., Arai, S., Hara, E., Kurokawa, M., 2019. Modeling ASXL1 mutation revealed impaired hematopoiesis caused by derepression of p16Ink4a through aberrant PRC1mediated histone modification. Leukemia 33(1), 191-204.

Unnikrishnan, A., Papaemmanuil, E., Beck, D., Deshpande, N.P., Verma, A., Kumari, A., Woll, P.S., Richards, L.A., Knezevic, K., Chandrakanthan, V., Thoms, J.A.I., Tursky, M.L., Huang, Y., Ali, Z., Olivier, J., Galbraith, S., Kulasekararaj, A.G., Tobiasson, M., Karimi, M., Pellagatti, A., Wilson, S.R., Lindeman, R., Young, B., Ramakrishna, R., Arthur, C., Stark, R., Crispin, P., Curnow, J., Warburton, P., Roncolato, F., Boultwood, J., Lynch, K., Jacobsen, S.E.W., Mufti, G.J., Hellstrom-Lindberg, E., Wilkins, M.R., MacKenzie, K.L., Wong, J.W.H., Campbell, P.J., Pimanda, J.E., 2017. Integrative Genomics Identifies the Molecular Basis of Resistance to Azacitidine Therapy in Myelodysplastic Syndromes. Cell Rep 20(3), 572-585.

Wang, X., Zhou, C., Qiu, G., Yang, Y., Yan, D., Xing, T., Fan, J., Tang, H., Peng, Z., 2012. Phospholipase C epsilon plays a suppressive role in incidence of colorectal cancer. Med Oncol 29(2), 1051-1058.

Wu, P., Weng, J., Li, M., Lu, Z., Deng, C., Sun, Q., Xu, R., Geng, S., Du, X., 2019. Co-occurrence of RUNX1 and ASXL1 mutations underlie poor response and outcome for MDS patients treated with HMAs. Am J Transl Res 11(6), 3651-3658.

Wymann, M.P., Schneiter, R., 2008. Lipid signalling in disease. Nat Rev Mol Cell Biol 9(2), 162-176.

Xiao, R., Sun, Y., Ding, J.H., Lin, S., Rose, D.W., Rosenfeld, M.G., Fu, X.D., Li, X., 2007. Splicing regulator SC35 is essential for genomic stability and cell proliferation during mammalian organogenesis. Mol Cell Biol 27(15), 5393-5402.

Xiao, W., Kawakami, Y., Kawakami, T., 2013. Immune regulation by phospholipase C-beta isoforms. Immunol Res 56(1), 9-19. 
Xie, C., He, Y., Zhen, M., Wang, Y., Xu, Y., Lou, L., 2017. Puquitinib, a novel orally available PI3Kdelta inhibitor, exhibits potent antitumor efficacy against acute myeloid leukemia. Cancer Sci 108(7), 1476-1484. Xie, M., Lu, C., Wang, J., McLellan, M.D., Johnson, K.J., Wendl, M.C., McMichael, J.F., Schmidt, H.K., Yellapantula, V., Miller, C.A., Ozenberger, B.A., Welch, J.S., Link, D.C., Walter, M.J., Mardis, E.R., Dipersio, J.F., Chen, F., Wilson, R.K., Ley, T.J., Ding, L., 2014. Age-related mutations associated with clonal hematopoietic expansion and malignancies. Nat Med 20(12), 1472-1478.

Yang, Y.R., Kang, D.S., Lee, C., Seok, H., Follo, M.Y., Cocco, L., Suh, P.G., 2016. Primary phospholipase C and brain disorders. Adv Biol Regul 61, 80-85.

Yip, B.H., Dolatshad, H., Roy, S., Pellagatti, A., Boultwood, J., 2016. Impact of Splicing Factor Mutations on Pre-mRNA Splicing in the Myelodysplastic Syndromes. Curr Pharm Des 22(16), 2333-2344.

Yip, B.H., Steeples, V., Repapi, E., Armstrong, R.N., Llorian, M., Roy, S., Shaw, J., Dolatshad, H., Taylor, S., Verma, A., Bartenstein, M., Vyas, P., Cross, N.C., Malcovati, L., Cazzola, M., Hellstrom-Lindberg, E., Ogawa, S., Smith, C.W., Pellagatti, A., Boultwood, J., 2017. The U2AF1S34F mutation induces lineage-specific splicing alterations in myelodysplastic syndromes. J Clin Invest 127(6), 2206-2221.

Yoshida, K., Sanada, M., Shiraishi, Y., Nowak, D., Nagata, Y., Yamamoto, R., Sato, Y., Sato-Otsubo, A., Kon, A., Nagasaki, M., Chalkidis, G., Suzuki, Y., Shiosaka, M., Kawahata, R., Yamaguchi, T., Otsu, M., Obara, N., Sakata-Yanagimoto, M., Ishiyama, K., Mori, H., Nolte, F., Hofmann, W.K., Miyawaki, S., Sugano, S., Haferlach, C., Koeffler, H.P., Shih, L.Y., Haferlach, T., Chiba, S., Nakauchi, H., Miyano, S., Ogawa, S., 2011. Frequent pathway mutations of splicing machinery in myelodysplasia. Nature 478(7367), 64-69. 